\title{
IN VITRO RUMINAL FERMENTATION AND DEGRADABILITY OF RICE HUSK ON RICE BRAN SUBSTITUTION
}

\author{
Rusli Fidriyanto*, Roni Ridwan, Wulansih Dwi Astuti, Rohmatussolihat, Nurul Fitri Sari, \\ Muh Watman, and Yantyati Widyastuti
}

Research Center for Biotechnology, Indonesian Institute of Sciences (LIPI), Indonesia

\begin{abstract}
Rice bran is a by-product of the rice milling process and has been well used as livestock feed. Rice bran is often adulterated with rice husk. The objective of this study was to evaluate the in vitro ruminal fermentation characteristics of rice bran with various compositions of rice husk and assess the relationship between rice husk addition and rice bran quality. The experiment was arranged in a completely randomized design with rice husk addition as a factor and three replications. Data of proximate value, gas production, ruminal degradability, and volatile fatty acid production were analyzed by analysis of variance. Moreover, significant effects of each treatment in the in vitro fermentation were further analyzed by Duncan's multiple range test $(\mathrm{P}<0.05)$. It was shown that the addition of rice husk to rice bran could increase acetic acid level, but it reduced potential gas production, gas production rate, organic matter and dry matter digestibility, and propionic acid level. Interestingly, the linear regression of dry matter digestibility, organic matter digestibility, and potential gas production showed the high adjusted $\mathrm{R}^{2}$ values. Moreover, this study also revealed that $10 \%$ of rice husk substitution on rice bran could significantly reduce the dry matter digestibility.
\end{abstract}

Keywords: rice bran, rice husk, digestibility, in vitro ruminal fermentation

${ }^{*}$ Corresponding author: Rusli Fidriyanto

Cibinong Science Center, Jl. Raya Bogor Km. 46, Cibinong 16911, Indonesia

Tel. +62-21-8754587, Fax. +62-21-87754588

E-mail.rusli.sbh@gmail.com

\section{Introduction}

Rice is a staple food for more than half of the world's population and mostly produced and consumed in Asia (Wani et al., 2012; Zou \& Yang, 2019). An increase in rice consumption is driven mainly by population growth and by the increased per capita consumption. An increase in rice production is followed by the increased by-product. The main by-products of rice are rice straw, rice husk, and rice bran. The rice kernel mainly consists of $70 \%$ endosperm, $20-21 \%$ rice husk, $6-8 \%$ rice bran, and $1 \%$ rice germ of the total seed weight (Zou \& Yang, 2019). Rice husk, the largest quantity of rice kernel by-product, mainly contains about $80 \%$ organic substance and $20 \%$ inorganic materials. Currently, most rice husk is underutilized or left unused because it has low nutritive value $(1.92-5.63 \%$ crude protein, $37.33-53.63 \%$ crude fiber, and $302.33 \mathrm{kcal} / \mathrm{kg}$ gross energy) (Telew et al., 2013; Amrullah et al., 2019).
Rice bran is a by-product of the rice milling process which has economic value. It contains nutrients of protein, fiber, amino acids, minerals, vitamins, and antioxidants (Younas et al., 2011). Rice bran has a long history of use in livestock feed as a source of protein and energy. Rice bran contains approximately 9.5$12.1 \%$ crude protein, $10.6-23.5 \%$ crude fiber, and $3165-3563 \mathrm{kcal} / \mathrm{kg}$ gross energy (Supriyati et al., 2015; Hardini, 2010; Warren \& Farrell, 1990; Oliveira et al., 2011). Several studies have been carried out to evaluate rice bran as cattle feed (Abrar et al., 2016; Wakabayashi et al., 2013; Gadberry et al., 2004).

Animal feeds account for $60-70 \%$ of the variable production costs in intensive livestock systems. In recent years, the price of rice bran has grown rapidly due to the high demand. Hence, rice bran is often adulterated with rice husk to get a lower price.

Presumably, a high content of rice husk will decrease the nutritive value of rice bran, because of the differences in nutrient content. A 
low-quality feed may decrease livestock productivity. However, the information about how much the content of rice husk in rice bran can be tolerated to maintain the quality of feed is not clear yet. Therefore, the objective of this study was to evaluate the fermentation characteristics of rice bran with various rice husk composition and assess the relationship between the compositional changes of rice husk with the quality of rice bran. The ruminal fermentation, including digestibility as well as proximate analysis of rice husk addition to rice bran were performed in this study.

\section{Materials and Methods}

\section{Materials}

Rice bran and rice husk were obtained from local suppliers. The materials were milled into 18 mesh flour and stored in polyethylene bags at $4{ }^{\circ} \mathrm{C}$ prior to further analysis.

\section{Methods}

The experiment was arranged in a completely randomized design with rice husk addition as a factor and 3 replications. The treatments were arranged according to the following experimental treatments (dry matter basis).

R1: 100\% Rice bran

R2: 90\% Rice bran : 10\% Rice husk R3: 80\% Rice bran : 20\% Rice husk R4: 70\% Rice bran : 30\% Rice husk R5: 60\% Rice bran : 40\% Rice husk R6: 50\% Rice bran : 50\% Rice husk R7: 40\% Rice bran : 60\% Rice husk R8: 30\% Rice bran : 70\% Rice husk R9: 20\% Rice bran : 80\% Rice husk R10: $10 \%$ Rice bran : 90\% Rice husk R11: 100\% Rice husk

The samples were analyzed for proximate analysis consist of dry matter content (Method No.930.15), ash content (Method No 930.05), crude protein content (Method No 978.04), crude fiber content (Method No 930.10), and crude fat content (Method No 930.09) (AOAC, 2005) and in vitro fermentation. For a confirmation study, different rice bran from another local supplier was used to test the equation to predict in vitro fermentation variable.

\section{In vitro ruminal fermentation}

In vitro ruminal fermentation technique of Theodorou et al., (1994) was followed with some modification. Ruminal fluid was collected from three rumen-fistulated Ongole crossbred cattle before morning feeding. Animal care procedures throughout the study followed protocols approved by the Ethical Clearance Committee of Indonesian Institute of Sciences (Number 9879/WK/HK/XI/2015). Rumen fluid was mixed in equal proportion, and filtered through four-layered cheesecloth, and immediately taken to the laboratory. Samples from each treatment were added to the serum bottle as much as $0.5 \mathrm{~g}$. Then, added by $50 \mathrm{ml}$ of rumen-McDougall buffer solution $(1: 2 \mathrm{v} / \mathrm{v})$, purged with oxygen-free $\mathrm{CO}_{2}$. Serum bottles sealed with a butyl rubber stopper and an aluminium crimp seal and transferred into an incubator at $39^{\circ} \mathrm{C}$.

Gas production was measured at 2, 4, 6, 8, $10,12,24$, and $48 \mathrm{~h}$ of incubation. After 48 -h of incubation, samples were taken for the measurements of $\mathrm{pH}$ value. Rumen-buffer mixture was separated by centrifugation (6,000 rpm, $10 \mathrm{~min})$ for volatile fatty acid (VFA) analysis. The VFA was analyzed using gas chromatography (GC 8A, Shimadzu Corp., Kyoto, Japan, with capillary column type containing $10 \%$ of SP-1200, $1 \%$ of $\mathrm{H}_{3} \mathrm{PO}_{4}$ on 80/100 Cromosorb WAW, and nitrogen as the gas carrier). Incubation was continued by mixing $50 \mathrm{~mL}$ pepsin- $\mathrm{HCl}$ with the substrate collected from centrifugation. Samples of dry matter digestibility (DMD) and organic matter digestibility (OMD) were taken after 48-h incubation. Thereafter, the substrate was separatedby vacuum filtration using Whatman ${ }^{\mathrm{TM}}$ filter papers No. 41. Dry matter and organic matter digestibility were calculated as the DM and OM which disappeared from the initial weight inserted into the tube, respectively.

\section{Confirmation study}

Confirmation study was performed to determine the difference between the estimated data values of in vitro parameters calculated by equations obtained from regression analysis with the observed data values from laboratory testing. Rice brans were obtained from different local suppliers. Samples were tested for proximate and in vitro analysis. The results of in vitro rumen fermentability parameter obtained through calculations using equations 
and laboratory analysis were analyzed using a completely randomized design with 3 replications.

\section{Statistical analysis}

All data were analyzed by SPSS 23 for windows. Data of proximate, gas production, rumen feed disappearance, and volatile fatty acid production were analyzed by using analysis of variance (ANOVA). Significant effects of each treatment were further analyzed by Duncan's multiple range test $(\mathrm{P}<0.05)$. Data of gas production were adjusted at the model proposed by Ørskov \& McDonald (1979) as p = $\mathrm{a}+\mathrm{b}\left(1-\mathrm{e}^{-\mathrm{ct}}\right)$ that $\mathrm{P}$ is the gas produced at time $t$, ' $a$ ' is the gas produced by the soluble fraction, ' $b$ ' is the gas produced by the insoluble but slowly fermenting fraction, ' $c$ ' is constant gas production rate, ' $t$ ' is the time of fermentation. Kinetic parameters of Ørskov'sequation were obtained by non-linear regression procedure. The correlation between the proximate variable and the rumen fermentation variable was obtained by the correlation coefficient Pearson analysis procedure. Moreover, the regression equation of proximate variable for estimating rumen fermentation variable estimation was obtained by linear regression procedure.

\section{Results}

The nutrient composition of rice bran with various ratios of rice husk addition is shown in Table 1. A pure rice bran (R1) consisted of 91.37\% dry matter, $90.59 \%$ organic matter, $10.8 \%$ crude protein, $11.53 \%$ ether extract, and $12.69 \%$ crude fiber. Moreover, rice husk (R11) used in this experiment was composed of $11.66 \%$ moisture, $20.69 \%$ ash, $1.04 \%$ crude protein, $2.06 \%$ ether extract, and $38.41 \%$ crude fiber.

Table 1. The effect of rice husk addition on proximate composition of rice bran

\begin{tabular}{|c|c|c|c|c|c|c|}
\hline Treatments & $\begin{array}{c}\text { Dry Matter } \\
(\%)\end{array}$ & $\begin{array}{c}\text { Organic matter } \\
(\%)\end{array}$ & $\begin{array}{l}\text { CP } \\
(\%)\end{array}$ & $\begin{array}{l}\text { CF } \\
(\%)\end{array}$ & $\begin{array}{l}\mathrm{EE} \\
(\%)\end{array}$ & $\begin{array}{l}\text { NFE } \\
(\%)\end{array}$ \\
\hline R1 & 91.37 & $90.59^{\mathrm{a}}$ & $10.80^{\mathrm{k}}$ & $12.69^{a}$ & $11.53 a$ & $55.55^{\mathrm{e}}$ \\
\hline $\mathrm{R} 2$ & 89.58 & $89.91^{\mathrm{ab}}$ & $9.20^{j}$ & $14.26^{\mathrm{a}}$ & $10.30 \mathrm{~b}$ & $56.15^{e}$ \\
\hline R3 & 89.59 & $88.67^{\mathrm{ab}}$ & $8.47^{\mathrm{i}}$ & $17.62^{\mathrm{b}}$ & $9.33 \mathrm{~b}$ & $53.25^{\text {de }}$ \\
\hline $\mathrm{R} 4$ & 89.19 & $87.10^{\mathrm{ab}}$ & $7.46^{\mathrm{h}}$ & $19.31^{\mathrm{b}}$ & $8.63 c$ & $51.69^{\text {cde }}$ \\
\hline R5 & 90.07 & $86.60^{\mathrm{ab}}$ & $6.31^{\mathrm{g}}$ & $22.60^{c}$ & 7.17d & $50.52^{\text {bcd }}$ \\
\hline R6 & 90.61 & $85.35^{\mathrm{ab}}$ & $5.51^{\mathrm{f}}$ & $24.63^{\text {cd }}$ & $5.54 d$ & $49.66^{\mathrm{bcd}}$ \\
\hline R7 & 89.77 & $84.03^{\mathrm{bc}}$ & $4.37^{e}$ & $28.27^{\text {de }}$ & $5.16 \mathrm{e}$ & $46.23^{\mathrm{b}}$ \\
\hline R8 & 89.69 & $85.88^{\mathrm{ab}}$ & $3.36^{\mathrm{d}}$ & $26.98^{e}$ & $4.03 \mathrm{f}$ & $50.51^{\text {cde }}$ \\
\hline R9 & 89.64 & $85.64^{\mathrm{ab}}$ & $2.32^{\mathrm{c}}$ & $31.96^{f}$ & $3.25 g$ & $48.11^{\mathrm{bc}}$ \\
\hline R10 & 89.88 & $84.64^{\mathrm{abc}}$ & $1.52^{\mathrm{b}}$ & $34.07^{f}$ & $2.68 \mathrm{~h}$ & $46.38^{\mathrm{b}}$ \\
\hline R11 & 88.34 & $79.31^{\mathrm{c}}$ & $1.04^{\mathrm{a}}$ & $38.41^{\mathrm{g}}$ & $2.06 \mathrm{i}$ & $37.80^{\mathrm{a}}$ \\
\hline \multicolumn{7}{|l|}{ P-value } \\
\hline Linier & $>0.05$ & $<0.05$ & $<0.05$ & $<0.05$ & $<0.05$ & $<0.05$ \\
\hline Quadratic & $>0.05$ & $>0.05$ & $<0.05$ & $>0.05$ & $<0.05$ & $<0.05$ \\
\hline
\end{tabular}

CP: crude protein, EE: Ether Extract; CF: Crude Fiber, NFE: Nitrogen Free Extract

${ }^{a-c}$ Means with different superscripts within columns significantly differed $(p<0.05)$.

It seemed that the increase in rice husk content in rice bran did not affect significantly its moisture content. This finding was in agreement with no significant difference between R1 and R11 on dry matter (Table 1). It is also shown that the addition of rice husk to rice bran could reduce crude protein, nitrogenfree extract, and ether extract compositions, while the ash content and crude fiber were increased significantly $(\mathrm{p}<0.05)$.

The gas production during 48 hours of incubation is presented in Figure 1. The result of this experiment showed that the gas was still being produced until 48 hours of incubation time in all treatments. This phenomenon indicated that the fermentable substrate remained present until 48 hours of incubation. Figure 1 also shows that the increase in rice husk composition could reduce gas production.

Moreover, the fermentation characteristics of rice bran are presented in Table 2. It was demonstrated that the substitution of rice husk on rice bran decreased significantly $(\mathrm{p}<0.05)$ potential gas production, gas production rate, 
and organic matter digestibility (OMD). The substitution of $10 \%$ rice husk on rice bran seemed not to decrease significantly the OMD to some extent.

Table 2. The effect of rice husk addition in rice bran on the in vitro ruminal fermentation

\begin{tabular}{|c|c|c|c|c|c|}
\hline Treatment & $\begin{array}{c}\mathrm{a}+\mathrm{b} \\
(\mathrm{mL})\end{array}$ & $\begin{array}{c}\mathrm{c} \\
(\mathrm{mL} / \mathrm{h})\end{array}$ & $\begin{array}{l}\mathrm{pH} \\
(\%) \\
\end{array}$ & $\begin{array}{c}\text { DMD } \\
(\%)\end{array}$ & $\begin{array}{c}\text { OMD } \\
(\%)\end{array}$ \\
\hline R1 & $111.37^{\mathrm{k}}$ & $0.066^{\mathrm{e}}$ & 6.71 & $61.53^{k}$ & $67.20^{j}$ \\
\hline R2 & $100.27^{j}$ & $0.058^{\mathrm{d}}$ & 6.76 & $58.15^{j}$ & $64.76^{\mathrm{j}}$ \\
\hline R3 & $93.24^{\mathrm{i}}$ & $0.057^{\mathrm{d}}$ & 6.72 & $54.33^{\mathrm{i}}$ & $60.36^{\mathrm{i}}$ \\
\hline $\mathrm{R} 4$ & $90.03^{\mathrm{h}}$ & $0.056^{\mathrm{d}}$ & 6.72 & $49.95^{\mathrm{h}}$ & $54.77^{\mathrm{h}}$ \\
\hline R5 & $85.33^{\mathrm{g}}$ & $0.053^{c}$ & 6.73 & $46.17^{\mathrm{g}}$ & $50.84^{\mathrm{g}}$ \\
\hline R6 & $71.96^{f}$ & $0.053^{c}$ & 6.76 & $40.33^{f}$ & $45.64^{\mathrm{f}}$ \\
\hline R7 & $64.31^{\mathrm{e}}$ & $0.053^{\mathrm{c}}$ & 6.71 & $34.95^{\mathrm{e}}$ & $40.39^{\mathrm{e}}$ \\
\hline R8 & $52.90^{\mathrm{d}}$ & $0.052^{\mathrm{C}}$ & 6.81 & $29.73^{\mathrm{d}}$ & $33.50^{d}$ \\
\hline R9 & $42.32^{c}$ & $0.053^{c}$ & 6.71 & $23.02^{c}$ & $28.16^{c}$ \\
\hline R10 & $31.73^{b}$ & $0.048^{\mathrm{b}}$ & 6.73 & $18.72^{\mathrm{b}}$ & $23.14^{\mathrm{b}}$ \\
\hline R11 & $28.16^{\mathrm{a}}$ & $0.038^{\mathrm{a}}$ & 6.59 & $13.61^{\mathrm{a}}$ & $18.99^{a}$ \\
\hline \multicolumn{6}{|l|}{ P-value } \\
\hline Linier & $<0.05$ & $<0.05$ & $>0.05$ & $<0.05$ & $<0.05$ \\
\hline Quadratic & $<0.05$ & $>0.05$ & $>0.05$ & $<0.05$ & $<0.05$ \\
\hline
\end{tabular}

Table 3.The effect of rice husk addition on partial volatile fatty acid (\%mM) and total volatile fatty acid $(\mathrm{Mmol} / \mathrm{ml})$ of rice bran in rumen fermentation

\begin{tabular}{lllllll}
\hline Treatment & C2 & C3 & C4 & Iso-C4 & C5 & Iso-C5 \\
\hline R1 & $52.60^{\mathrm{a}}$ & $26.11^{\mathrm{c}}$ & $11.56^{\mathrm{a}}$ & $3.79^{\mathrm{ab}}$ & 4.09 & 1.85 \\
R2 & $54.09^{\mathrm{ab}}$ & $19.33^{\mathrm{ab}}$ & $14.51^{\mathrm{cd}}$ & $4.28^{\mathrm{abc}}$ & 4.42 & 3.37 \\
R3 & $55.79^{\mathrm{b}}$ & $20.48^{\mathrm{b}}$ & $12.15^{\mathrm{ab}}$ & $6.06^{\mathrm{d}}$ & 3.75 & 1.77 \\
R4 & $55.18^{\mathrm{b}}$ & $19.75^{\mathrm{ab}}$ & $12.56^{\mathrm{ab}}$ & $5.83^{\mathrm{d}}$ & 4.17 & 2.50 \\
R5 & $54.90^{\mathrm{b}}$ & $19.26^{\mathrm{ab}}$ & $14.63^{\mathrm{cd}}$ & $3.21^{\mathrm{a}}$ & 5.70 & 2.30 \\
R6 & $54.45^{\mathrm{ab}}$ & $18.69^{\mathrm{ab}}$ & $15.18^{\mathrm{cd}}$ & $4.11^{\mathrm{abc}}$ & 5.62 & 1.95 \\
R7 & $55.06^{\mathrm{b}}$ & $18.80^{\mathrm{ab}}$ & $15.77^{\mathrm{d}}$ & $4.38^{\mathrm{abc}}$ & 4.12 & 1.87 \\
R8 & $55.63^{\mathrm{b}}$ & $16.91^{\mathrm{a}}$ & $14.47^{\mathrm{cd}}$ & $5.06^{\mathrm{bcd}}$ & 5.91 & 2.03 \\
R9 & $56.04^{\mathrm{b}}$ & $17.42^{\mathrm{a}}$ & $13.59^{\mathrm{bc}}$ & $4.90^{\mathrm{bcd}}$ & 5.61 & 2.45 \\
R10 & $56.02^{\mathrm{b}}$ & $17.68^{\mathrm{ab}}$ & $13.61^{\mathrm{bc}}$ & $5.26^{\mathrm{cd}}$ & 5.53 & 1.90 \\
R11 & $55.92^{\mathrm{b}}$ & $17.05^{\mathrm{a}}$ & $14.36^{\mathrm{cd}}$ & $6.14^{\mathrm{d}}$ & 4.20 & 2.33 \\
P-value & & & & & \\
Linier & $<0.05$ & $<0.05$ & $<0.05$ & $<0.05$ & $>0.05$ & $>0.05$ \\
Quadratic & $>0.05$ & $<0.05$ & $<0.05$ & $>0.05$ & $>0.05$ & $>0.05$ \\
\multicolumn{7}{l}{ C2: acetic acid, C3: propionic acid, C4: butyric acid, Iso-C4: Isobutyric acid,C5: valeric } \\
acid, Iso-C5: Iso-valeric acid, T.VFA: total volatile fatty acid \\
a-c Means with different superscripts within columns significantly differed (p<0.05).
\end{tabular}

However, decreases in dry matter digestibility (DMD), gas production rate, and potential gas production by $5.49 \%, 12.12 \%$, and 9.96\%, respectively were observed. Additionally, the effect of rice husk addition to rice bran was likely to lead to the formation of high production of acetic acid, but low level of propionic acid (Table 3).
In terms of crude protein and ether extract contents of rice bran, they had shown positive correlations with DMD, OMD, propionic acid and iso valerate concentrations, potential gas production, and also gas production rate but had shown negative correlations with acetate and butyrate concentrations (Table 4). 
However, the crude fiber content had shown positive correlations with butyrate and acetate concentrations, while its negative correlations with DMD, OMD, propionic acid concentration, potential gas production, and gas production rate were observed. The ash content was negatively correlated with DMD, OMD, acetate, butyrate, and valerate concentrations, potential gas production, and gas production rate (Table 4).

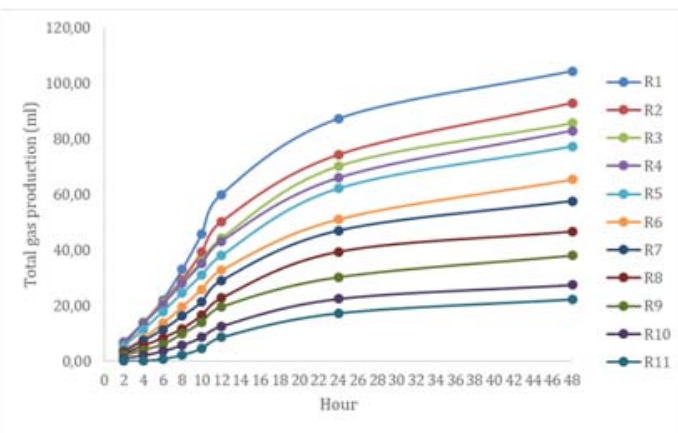

Figure 1. Gas production during 48 hours of incubation

As presented in Table 4, the correlation matrix between rice bran nutrition and rumen fermentation variables is used to describe which parameters correlate. Variables that have correlations were analyzed by the regression methods to get equations (Table 5). These equations can be used to estimate rumen fermentation variables (DMD, OMD, acetate, propionic, butyrate concentrations, potential gas production, and gas production rate) from rice bran nutrient variables (ash, crude protein, crude fiber, and ether extract). In this study, the models of in vitro ruminal fermentation parameter estimation by rice bran nutrients were fitted to the linear regression models. The linear regressions to estimate DMD, OMD, and potential gas production had high adjusted $\mathrm{R}^{2}$ values by $0.977(\mathrm{P}<0.05)$, $0.973 \quad(\mathrm{P}<0.05)$, and $0.976 \quad(\mathrm{P}<0.05)$, respectively (Table 5).

The equations for estimating DMD, acetate and propionate concentrations, potential gas production, and gas production rate were significantly different $(\mathrm{P}<0.05)$. According to a confirmation study (Table 6), there were differences between the estimated value by the calculated equation and the observed value by the laboratory analysis on DMD and propionate concentration.

Table 4. Matrix correlation between proximate and rumen fermentation variables

\begin{tabular}{ccccccc}
\hline Variable & Treatment & Moisture & Ash & CP & CF & EE \\
\hline DMD & $-.995^{* *}$ & -.146 & $-.650^{* *}$ & $.987^{* *}$ & $-.972^{* *}$ & $.979^{* *}$ \\
OMD & $-.995^{* *}$ & -.163 & $-.648^{* *}$ & $.987^{* *}$ & $-.965^{* *}$ & $.980^{* *}$ \\
C2 & $.563^{* *}$ & .269 & $.416^{*}$ & $-.579^{* *}$ & $.562^{* *}$ & $-.555^{* *}$ \\
C3 & $-.701^{* *}$ & -.159 & -.284 & $.712^{* *}$ & $-.675^{* *}$ & $.711^{* *}$ \\
C4 & $.382^{*}$ & .021 & $.355^{*}$ & $-.398^{*}$ & $.357^{*}$ & $-.416^{*}$ \\
Iso-C4 & .308 & .340 & .277 & -.281 & .278 & -.267 \\
C5 & .235 & -.168 & $-.350^{*}$ & -.236 & .227 & -.268 \\
Iso-C5 & -.125 & -.105 & -.109 & .109 & -.110 & .152 \\
a+b & $-.992^{* *}$ & -.155 & $-.652^{* *}$ & $.987 * *$ & $-.963^{* *}$ & $.976^{* *}$ \\
C & $-.880^{* *}$ & -.180 & $-.723^{* *}$ & $.866^{* *}$ & $-.887^{* *}$ & $.851^{* *}$ \\
pH & -.199 & .212 & -.018 & .164 & -.285 & .134 \\
\hline
\end{tabular}

CP: crude protein, EE: Ether Extract, CF: Crude Fiber, C2: acetic acid, C3: propionic acid, C4: butyric acid, Iso-C4: Isobutyric acid, C5: valeric acid, Iso-C5: Isovaleric acid, a+b: potential gas production, c: gas production rate, DMD: dry matter digestibility, OMD: organic matter digestibility

**. Correlation is significant at the 0.01 level.

*. Correlation is significant at the 0.05 level.

\section{Discussion}

Protein from rice bran is well used for cattle because it is consist of a higher lysine content as compared to oat, maize, and wheat protein (Juliano, 1985; Wang et al., 2015; Amagliani et al., 2017; Mota et al., 2016). Rice husk used in this experiment consisted of $11.66 \%$ moisture, $20.69 \%$ ash, $1.04 \%$ crude protein, $2.06 \%$ ether extract, and $38.41 \%$ crude 
fiber. Rice husk ash is composed mainly of silica, which values range from $87.4 \%$ to $91.4 \%$ (Alvarez et al., 2014; Valverde et al., 2007; Van et al., 2014).

The fermentable substrate decreasesas the incubation time increases and leads to a decreasein gas production rate (Hungate, 1966; Jayanegara \& Sofyan, 2008). In the early time of incubation, the treatments which consisted of higher rice bran ratios showed the higher gas production. It could be due to the presence of readily fermentable substrate in rice bran. The decreased in vitro rumen fermentability parameter could be the result of the decreased protein and the increased fiber in rice bran. A lower degradability of rice bran caused by a higher rice husk addition is in line with the observation of lower gas production in this study. The substitution of $10 \%$ rice husk (R2) significantly decreased DMD, but it did not effect OMD. It is suggested that the increases in fiber and silica content from rice husk were not enough to significantly reduce OMD.

The increase of rice husk portion will increase the fiber content. Fiber in rice husk consists of $28.6 \%-41.5 \%$ cellulose, $14.0 \%$ 28.6\% hemicellulose, and 20.4\%-33.7\% lignin (Muhammad et al., 2013; Quispe et al., 2017). Ash content mainly consists of silica (Vlaev et al., 2003).

Table 5. Regression equation of proximate for rumen fermentation variable estimation

\begin{tabular}{llccc}
\hline Variable & Equation & $\begin{array}{c}\text { Adjusted } \\
\mathrm{R}^{2}\end{array}$ & $\mathrm{~S}_{\mathrm{e}}$ & P-Value \\
\hline DMD & $\mathrm{Y}=30.475+3.888 \mathrm{X}_{1}-0.532 \mathrm{X}_{2}+0.104 \mathrm{X}_{3}-0.162 \mathrm{X}_{4}$ & 0.977 & 2.41 & $<0.05$ \\
OMD & $\mathrm{Y}=24.89+4.099 \mathrm{X}_{1}-0.292 \mathrm{X}_{2}+0.127 \mathrm{X}_{3}+0.375 \mathrm{X}_{4}$ & 0.973 & 2.69 & $<0.05$ \\
$\mathrm{C} 2$ & $\mathrm{Y}=54.695-0.525 \mathrm{X}_{1}+0.032 \mathrm{X}_{2}+0.008 \mathrm{X}_{3}-0.370 \mathrm{X}_{4}$ & 0.259 & 1.17 & $<0.05$ \\
$\mathrm{C} 3$ & $\mathrm{Y}=5.774+0.956 \mathrm{X}_{1}+0.127 \mathrm{X}_{2}+0.264 \mathrm{X}_{3}+0.215 \mathrm{X}_{4}$ & 0.529 & 1.92 & $<0.05$ \\
$\mathrm{C} 4$ & $\mathrm{Y}=18.546+0.267 \mathrm{X}_{1}-0.112 \mathrm{X}_{2}+0.068 \mathrm{X}_{3}-0.685 \mathrm{X}_{4}$ & 0.111 & 1.42 & $>0.05$ \\
$\mathrm{a}+\mathrm{b}$ & $\mathrm{Y}=38.16+8.435 \mathrm{X}_{1}-0.475 \mathrm{X}_{2}+0.205 \mathrm{X}_{3}-0.859 \mathrm{X}_{4}$ & 0.976 & 4.62 & $<0.05$ \\
$\mathrm{C}$ & $\mathrm{Y}=0.082+0.0001 \mathrm{X}_{1}-0.001 \mathrm{X}_{2}+0.0001 \mathrm{X}_{3}-0.001 \mathrm{X}_{4}$ & 0.813 & 0.003 & $<0.05$ \\
\hline
\end{tabular}

$\mathrm{X}_{1}$ :Crude Protein, $\mathrm{X}_{2}$ :Crude Fiber, $\mathrm{X}_{3}$ :Ash, $\mathrm{X}_{4}$ :Ether Extract, $\mathrm{S}_{\mathrm{e}}$ : Standard error

Table 6. Comparison between estimation by equation and laboratory analysis on in vitro fermentation parameter

\begin{tabular}{lccc}
\hline Variables & $\begin{array}{c}\text { Estimated value by } \\
\text { equations }\end{array}$ & $\begin{array}{c}\text { Observed value } \\
\text { by laboratory } \\
\text { experiments }\end{array}$ & SEM \\
\hline DMD (\%) & 60.37 & 61.86 & 0.24 \\
OMD (\%) & $67.77^{\mathrm{a}}$ & $65.11^{\mathrm{b}}$ & 0.64 \\
C2 $(\% \mathrm{mM})$ & $45.23^{\mathrm{a}}$ & $52.01^{\mathrm{b}}$ & 1.52 \\
C3 $(\% \mathrm{mM})$ & 22.44 & 24.57 & 0.64 \\
C4 (\%mM) & $11.78^{\mathrm{a}}$ & $13.64^{\mathrm{b}}$ & 1.71 \\
$\mathrm{a}+\mathrm{b}(\mathrm{ml})$ & $105.73^{\mathrm{a}}$ & $101.24^{\mathrm{b}}$ & 1.14 \\
c (ml/jam) & $0.060^{\mathrm{a}}$ & $0.080^{\mathrm{b}}$ & 0.004 \\
\hline
\end{tabular}

*Rice bran was consist of: moisture: 9.46\%, Crude Protein: 9.66\%, Crude fiber:10.85\%, Extract ether: 13.09\%, Ash: $12.28 \%$

C2: acetic acid, C3: propionic acid, C4: butyric acid, Iso-C4: Isobutyric acid,C5: valeric acid, Iso-C5: Isovaleric acid, a+b: potential gas production, c: gas production rate, DMD: dry matter digestibility, OMD: organic matter digestibility

Lignocellulose and silica are difficult to degrade in the rumen (Fonnesbeck et al., 1981). The effect of rice husk addition to rice bran leads to the formation of high production of acetic acid but the decreased propionic acid concentration (Table 3). The increase in acetic acid production was likely due to the increased crude fiber content and the decreased protein content in rice bran. Moreover, it has been reported that the increase in dietary fiber can elevate acetate production (Valadares et al., 1999).

Similar findings were also reported by Olfaz et al., (2018) and Jayanegara et al., (2009). There were positive relationships between ether extract and crude protein with 
potential gas production, gas production rate, and OMD. According to Fonnesbeck et al., (1981) and De Boever et al. (2005), the increase in nutrient digestibility will be in line with the increases in carbohydrates and crude protein contents, but it is negatively correlated with the increase in fiber content. Sari et al. (2018) and Fidriyanto et al.(2019) also reported that DMD and OMD was decreased with the increase in fiber content. It seemed that the negative correlation could be attributed to the ash composition in rice bran. It consists of inorganic matters of mineral and silica (Satter et al., 2014; Rosniyana et al., 2007). Because ash is difficult to digest, a higher ash content in feed will reduce digestibility. The findings of rice husk addition in this study supported the fact that rice husk addition to rice bran may contribute to the reduction of nutritive value, in vitro gas production, and rumen degradability.

Adulteration of rice bran with rice husk seemed to decreasethe quality and rumen degradability of rice bran. Moreover, the increased rice husk content could reduce protein content, gas production, and digestibility. The results showed that $10 \%$ of rice husk substitution on rice bran significantly reduced DMD. The relationship and regression equation of nutrient and in vitro ruminal fermentation was found in this study. It is apparent that the equation can be used to estimate in vitro ruminal fermentation from rice bran nutrients.

\section{Acknowledgments}

The authors wish to acknowledge the financial support received from 'DIPA Technopark Banyumulek'” Research Center for Biotechnology, Indonesian Institute of Science 2019-2020 for supporting this publication.

\section{References}

Abrar, A., Kondo, M., Kitamura, T., Ban-Tokuda, T., \& Matsui, H. (2016). Effect of supplementation of rice bran and fumarate alone or in combination on in vitro rumen fermentation, methanogenesis and methanogens. Animal Science Journal, 87, 398404. https://doi.org/10.1111/asj.12431.

Alvarez, J., Lopez, G., Amutio, M., Bilbao, J. \& Olazar, M. (2014). Bio-oil production from rice husk fast pyrolysis in a conical spouted bed reactor. Journal Fuel, 128, 162169.https://doi.org/10.1016/j.fuel. 2014.02.074.

Amagliani, L., O’regan, J., Kelly, A.L., \& O’Mahony, J.A. (2017). Composition and protein profile analysis of rice protein ingredients. Journal of Food Composition and Analysis, 59, 18-26. https://doi.org/10.1016/ j.jfca.2016.12.026.

Amrullah, M., Muda B.I., Tampoebolon, \& Prasetyono, B.W. (2019). Kajian pengaruh proses fermentasi sekam padi amoniasi menggunakan Aspergillus niger terhadap serat kasar, protein kasar, dan total digestible nutrients. Jurnal Pengembangan Penyuluhan Peternakan,16 (29), 25-31.

AOAC. (2005). Official Methods of Analysis of AOAC International, 18th edition. AOAC International, Gaithersburg.

De Boever, J. L., Aerts, J. M., Vanacker, J. M., \& De Brabander, D. L. (2005). Evaluation of the nutritive value of maize silages using a gas production technique. Animal Feed Science and Technology, 123,255-265. https://doi.org/10.10 16/ j.anifeedsci.2005.04.019.

Fidriyanto, R., Ridwan, R., Rohmatussolihat, Astuti, W. D., Sari, N. F., Adi, E. B. M., Mulyaningsih, E. S. \& Widyastuti, Y. (2019). In vitro rumen fermentability kinetics of parboiled rice bran. Journal of the Indonesian Tropical Animal Agriculture, 44 (1), 96-105. https://doi.org/10.14 710/jitaa.44.1.96-105.

Fonnesbeck, P. V., Christiansen,J. L., \& Harris, L. E. (1981). Factors affecting digestibility of nutrients by sheep. Journal of Animal Science, 52, 363-376. https://doi.org/10.2527/jas 1981.522363x

Gadberry, M. S., Beck, P. A., \& Gunter, S. A. (2004). Forage intake and performance of beef heifers grazing cool-season pastures and supplemented with de-oiled rice bran or corn. The Professional Animal Scientist,20, 394400.https://doi.org/10.15232/S10807446(15) 31337-1.

Hardini. (2010). The nutrient evaluation of fermented rice bran as poultry feed. The International Journal of Poultry Science, 9(2),152-154.

Hungate, R. E. (1966). The Rumen and Its Microbes. Academic Press, New York.

Jayanegara, A. \& Sofyan, A. (2008). Penentuan aktifitas biologis tannin beberapa hijauan secara in vitro menggunakan 'Hohenheim Gas Test' 
dengan polietilen glikol sebagai determinan. Media Peternakan, 31 (1),44-52.

Jayanegara, A., N. Togtokhbayar, H.P.S. Makkar \& K. Becker. (2009). Tannins determined by various methods as predictors of methane production reduction potential of plants by an in vitro rumen fermentation system. Journal of Food Science and Technology, 150, 230-237. https://doi.org/10.1016/ j.ani- feedsci. 2008.10.011.

Juliano, B.O. (1985). Rice bran. In: Juliano, B.O. (Ed.), Rice Chemistry and Technology, 647-680. St. Paul, MN: American Association of Cereal Chemists.

Mota, C., Santos, M., Mauro, R., Samman, N., Matos, A.S., Torres, D., \& Castanheira. (2016). Protein content and amino acids profile of pseudocereals. Food Chemistry, 193,5561.https://doi.org/10.1016/j.foodchem.2014.11. 043.

Muhammad, S., Bakar, A., \& Titiloye, J.O. (2013). Catalytic pyrolysis of rice husk for bio-oil production. Journal of Analytical and Applied Pyrolysis, 103,362-368. https://doi. org/10.1016/ j.jaap.2012.09.005.

Olfaz, M., Kilic, U., Boga, M., \& Abdi, A.M. (2018). Determination of the in vitro gas production and potential feed value of olive, mulberry, and sour orange tree leaves. Journal of Open Life Sciences, 13,269-278. https:// doi.org/10.1515/ biol-2018-0033.

Oliveira, M. S., Feddern, V., Kupski, L., Cipolatti, E. P., Badiale-Furlong, E., \& Souza-Soares, L. A. (2011). Changes in lipid, fatty acids and phospholipids composition of whole rice bran after solid-state fungal fermentation. Bioresource Technology, 102, 8335-8338. https://doi.org/ 10.1016/ j.bior- tech.2011.06.025.

Ørskov, E. R \& Mcdonald, I. (1979). The estimation of protein degradability in the rumen from incubation measurements weighted according to rate of passage. Journal of Agricultural Science, 92(2), 499-503. https://doi.org/10.1017/S00218 59600063048.

Quispe, I., Navia, R. \& Kahhat, R. (2017). Energy potential from rice husk through direct combustion and fast pyrolysis: A review. Journal of Waste Management, 59, 200-210. https://doi.org/10.1016/j.wasman.2016.10.001.

Rosniyana, A., Hashifah, M.A., \& Shariffah Norin, S.A. (2007). The physico-chemical properties and nutritional composition of rice bran produced at different milling degrees of rice. Journal of
Tropical Agriculture and Food Science. 35(1),99-105.

Sari, N. F., Ridwan, R., Rohmatussolihat., Fidriyanto, R., Astuti, W. D., \& Widyastuti, Y. (2018). Characteristic of different level of fermented concentrate in the rumen metabolism based on in vitro. Journal of the Indonesian Tropical Animal Agriculture, 43(3), 296305.https://doi.org/ 10.14710/jitaa.43.3. 296305.

Satter, M.A., Ara, H., Jabin, S.A., Abedin, N., Azad, A.K., Hossain, A., \& Ara, U. (2014). Nutritional composition and stabilization of local variety rice bran BRRI-28. International Journal of Science and Technology,3 (5),306-313.

Supriyati, Haryanti, T., Susanti, T., \& Susana, I.W.R. (2015). Nutritional value of rice bran fermented by Bacillus amyloliquefaciens and humic substances and its utilization as a feed ingredient for broiler chickens. AsianAustralasian Journal of Animal Sciences ,28:231-238. http://dx.doi.org/10.5713/ajas.14. 0039 .

Telew, C., Kereh, V.G., Untu, I.M., \& Rembet, B.W. (2013). The improvement of the rice husks nutritional value with a biotechnology "Effective Micro-organisms" (EM4) as an organic feed ingredient. Jurnal Zootek, 32 (5), 1 - 8.

Theodorou, M.K., Williams, B.A., Dhanoa, M.S., McAllan, A.B., \& France, J. (1994). A simple gas production method using a pressure transducer to determine the fermentation kinetic of ruminant feeds. Animal Feed Science and Technology,48, 185-197.https://doi.org/10.1016/03778401(94)90171-6.

Valadares R.F.D, Broderick G.A, Filho S.C. V., \& Clayton M. K. (1999). Effect of replacing alfalfa silage with high moisture corn on ruminal protein synthesis estimated from excretion of total purine derivatives. Journal of Dairy Science, 82 (12), 2686-2696. https://doi.org/10.3168/jds.S00220302(99)75525-6.

Valverde, A., Sarria, B., \& Monteagudo, J.P. (2007). Comparative analysis of the physicochemicals characteristics of the rice husk. Scientia et Technica, 37, 255- 260.

Van, V.T.A., Rößler, C., Bui, D.D., \& Ludwig, H.M. (2014). Pozzolanic reactivity of mesoporous amorphous rice husk ash in portlandite solution. Journal of Construction and Building Materials, 59,111-119.

https://doi.org/10.1016/j.conbuildmat.2014.02.0 46. 
Vlaev, L.T., Markovska, I.G., \& Lyubchev, L.A. (2003). Non-isothermal kinetics of pyrolysis of rice husk. Thermochimica Acta, 406,1-7. https://doi.org/10.1016/S0040-6031(03)002223.

Wakabayashi, H., Fukushima, N., Ito, K., Nishikawa, A., Yoshimi, R., Ogawa, Y., Yoneda, S., Ban-Tokuda, T., \& Wakita, M. (2013). Effect of raw rice bran supplementation on rumen methanogen population density and in vitro rumen fermentation. Japanese Society of Grassland Science, Grassland Science, 59, 129134. https://doi.org/10.1111/grs.12023.

Wang, J., Shimada, M., Kato, Y., Kusada, M. \& Nagaoka, S. (2015). Cholesterol-lowering effect of rice bran protein containing bile acid-binding proteins. Journal of Bioscience, Biotechnology, and Biochemistry,79 (3),456-461.https://doi.org/ 10.1080/ 0916-8451.2014.978260.

Wani, A.A., Singh, P., Shah, M.A., SchweiggertWeisz, U., Gul, K., \& Wani, I.A. (2012). Rice
Starch Diversity: Effects on Structural, Morphological, Thermal, and Physico-chemical Properties-A Review. Compre-hensive Reviews in Food Science and Food Safety, 11(5), 417-436. https:// doi.org/10.1111/j.1541-4337.2012. 00193.x.

Warren, B. E., \& Farrell, D. J. (1990). The nutritive value of full-fat and defatted Australian rice bran. IV. Egg production of hens on diets with defatted rice bran. Animal Feed Science and Technology, 27 (3), 247-257. https://doi.org/10.1016/03778401(90)90087-O.

Younas, A., Bhatti, M.S., Ahmed, A., \& Randhawa, M.A. (2011). Effect of rice bran supplementation on cookie baking quality. Pakistan Journal of Agricultural Sciences, 48, 129-134.

Zou, Y., \& Yang, T. (2019). Rice husk, rice husk ash and their applications. Rice bran and rice bran oil: Chapter 9, 207-246. London: Academic Press and AOCS Press. 